\title{
Case Study on Ventilation Method Development for Bar-Boljare Highway Tunnels Construction in Montenegro
}

\author{
ALEKSANDAR S. CVJETIĆ, University of Belgrade, \\ Faculty of Mining and Geology, Belgrade \\ NIKOLA M. LILIĆ, University of Belgrade, \\ Faculty of Mining and Geology, Belgrade \\ VOJIN B. ČOKORILO, University of Belgrade, \\ Faculty of Mining and Geology, Belgrade \\ VLADIMIR M. MILISAVLJEVIĆ, University of Belgrade, \\ Faculty of Mining and Geology, Belgrade
}

\begin{abstract}
Sometimes tunnel construction is a necessity regardless of its purpose due to many reasons, to mention some of them: limited space, safe operation, environmental protection etc. In those cases, one of the main aspects concerning an appropriate design of a tunnel construction is site ventilation. Ventilation is required during the construction of any tunnel regardless of technology used to construct it. Three major construction ventilation schemes are typically applied. Which one will be use are often in dependency of the site requirements. In this paper is presented case study on ventilation method development for the highway tunnels construction and it includes ventilation solutions for tunnels "Suka", "Vežešnik", "Mrke" and Vjeternik" during construction phase. The tunnels are part of the Bar-Boljare highway which is also a part of the Trans-European Highway (THE) through the Republic of Montenegro.
\end{abstract}

Key words: tunnelling, ventilation, Bar-Boljare highway

\section{INTRODUCTION}

"The necessity for tunnels and the benefits they bring cannot be overestimated. Tunnels improve connections and shorten lifelines. Moving traffic underground, they improve the quality of life above ground and may have enormous economic impact" [1]. Sometimes tunnel construction is a must regardless of its purpose due to limited space, safe operation, environmental protection etc. The construction of tunnels is risky and expensive. One of the main aspects concerning an appropriate design of a tunnel construction is site ventilation. In other words, ventilation is required during the construction of any tunnel, whether the tunnel is constructed by blasting, boring or placing prefabricated tubes in a trench.

Blasting, boring and several other activities during

Author'a address: Aleksandar Cvjetić, University of Belgrade, Faculty of Mining and Geology, Belgrade, Đušina 7

e-mail: aleksandar.cvjetic@ rgf.bg.ac.rs

Paper received: 18.08.2017.

Paper accepted: 08.09.2017. a tunnel construction are followed by production of dust mist, fumes, toxic and flammable gases. These contaminants must and can only be removed by ventilation in order to provide a suitable, safe working environment for the construction workers. Among other requisites ventilation systems for construction sites must be flexible to can grow and moving with the construction progress. Sometimes it implies rather complex flow pattern including leakage flows, booster stations, filtering, conjunctions and disjunctions etc.

Nowadays three major construction ventilation schemes are typically applied [2], use of which are often in dependency of the site requirements:

- forced ventilation - employing flexible ducts to introduce fresh air directly to the work sites;

- exhaust ventilation - sucking consumed and loaded air out of the tunnel employing reinforced flexible ducts or spiral steel ducts;

- circulation ventilation schemes - mainly used in double bore projects, where fresh air is introduced via one bore and consumed air is extracted via the second. 
There are at least two factors which the actual choice of the ventilation system for a specific site depends on. One is the complexity of the project (excavation length and diameter, single or double bore, cooling requirements, intermediate multifunction stations, etc.).
The second one is the national or local legislation, directives, codes and guidelines, which may differ largely from one country to another. Table. 1 compares some of the differences between prescriptions in France, Switzerland and Italy. [2]

Table 1. Comparison of prescriptions [2]

\begin{tabular}{|l|l|l|l|l|l|}
\hline Value & $\begin{array}{l}\text { France } \\
\text { CNAM }\end{array}$ & $\begin{array}{l}\text { France } \\
\text { AFTES }\end{array}$ & Switzerland & $\begin{array}{l}\text { Italy: Emilia- } \\
\text { Romagna }\end{array}$ & $\begin{array}{l}\text { Italy: } \\
\text { Piemonte }\end{array}$ \\
\hline $\begin{array}{l}\text { Fresh air need } \\
\text { per CV Diesel }\end{array}$ & $50 \mathrm{l} / \mathrm{s}$ & $50 \mathrm{1} / \mathrm{s}$ & $\begin{array}{l}\text { work: } 50-74 \mathrm{l} / \mathrm{s} \\
\text { transport: } 25-37 \mathrm{l} / \mathrm{s} \text { max. } \\
\text { without filter }\end{array}$ & $50 \mathrm{l} / \mathrm{s}$ & $50 \mathrm{l} / \mathrm{s}$ \\
\hline Min. air speed & $0.3 \mathrm{~m} / \mathrm{s}$ & $0.5 \mathrm{~m} / \mathrm{s}$ & $0.3 \mathrm{~m} / \mathrm{s}\left(0.5 \mathrm{~m} / \mathrm{s}\right.$ if $\left.\mathrm{CH}_{4}\right)$ & $0.2 \mathrm{~m} / \mathrm{s}$ & $0.3 \mathrm{~m} / \mathrm{s}$ \\
\hline Max. air speed & & $1.5 \mathrm{~m} / \mathrm{s}$ & & & $25^{\circ} \mathrm{C}$ wet bulb \\
\hline $\begin{array}{l}\text { Temperature, } \\
\text { work site }\end{array}$ & $26^{\circ} \mathrm{C}$ humid & $28^{\circ} \mathrm{C}$ dry & blowing & exhaust \\
\hline $\begin{array}{l}\text { Recommended } \\
\text { type }\end{array}$ & exhaust & exhaust & circul., blowing & & \\
\hline
\end{tabular}

From the table 1 it is obvious that the both French recommendations emphasize the importance of efficient dust and blasting fume capture at its origin and removal to the exterior employing the exhaust ventilation systems. [3, 4].

As for fresh air needs, only the Swiss values differ somewhat in function of Diesel engine dust-filter presence and also the type of the engine employment: at the work front or down road in the tunnel. [5]

Regarding the upper limit of air speed, French AFTES is the only document which defines an upper limit for air speed $(1.5 \mathrm{~m} / \mathrm{s})$. The same recommendation, French AFTES is the most restrictive requiring a least $0.5 \mathrm{~m} / \mathrm{s}$.

Road Belgrade-Adriatic Sea is extension of TransEuropean Highway (TEH) which connects main TEH route (Gdansk, Poland and Athens, Greece and Istanbul, Turkey) with the Adriatic Sea in the Montenegro. Bar-Boljare highway is part of the TEH through Montenegro. This road is part of the E-80 and E-65 routes, meaning that it is simultaneously a part of longitudinal and transversal motorway grid in Europe. The present paper is focused on the Bar-Boljare highway tunnels construction ventilation project.

This Project is based on the contract between the Bemax company, from Podgorica, as Purchaser and Volmont company from Podgorica, and it includes ventilation solutions for tunnels "Suka", "Vežešnik", "Mrke" and Vjeternik" during construction phase. [6]

\section{TECHNICAL DESCRIPTION OF THE TUNNEL VENTILATION DURING CONSTRUCTION}

To finalize task of construction of tunnels "Suka", "Vežešnik", "Mrke" and "Vjeternik" ventilation is designed in the construction stage of the tunnels. Ventilation will be organized as forcing auxiliary ventilation of underground openings.

Auxiliary ventilation is achieved by axial auxiliary fans in forcing mode and flexible ducts of various maximal lengths up to the face of workings. Ducts are placed along the roof of each tunnel's tube (Table 2).

Table 2. Overview of maximal lengths of auxiliary ventilation

\begin{tabular}{|l|l|l|l|l|l|}
\hline Tunnel & $\begin{array}{l}\text { Number of } \\
\text { tubes }\end{array}$ & $\begin{array}{l}\text { Cross-section area } \\
\left(\mathrm{m}^{2}\right)\end{array}$ & $\begin{array}{l}\text { Length of left tube } \\
(\mathrm{m})\end{array}$ & $\begin{array}{l}\text { Length of right tube } \\
(\mathrm{m})\end{array}$ & $\begin{array}{l}\text { Max. length of } \\
\text { auxiliary ventilation } \\
(\mathrm{m})\end{array}$ \\
\hline Suka & 2 & 68 & 721.42 & 625.41 & 740 \\
\hline Vežešnik & 2 & 68 & 2486.27 & 2417.37 & 1280 \\
\hline Mrke & 2 & 68 & 802.00 & 829.00 & 860 \\
\hline Vjeternik & 2 & 68 & 3042.05 & 2907.53 & 1540 \\
\hline
\end{tabular}

Auxiliary ventilation includes positioning of fan at the purpose built base outside of the tunnel (Figure 1), approximately $20 \mathrm{~m}$ away from the entrance into the tunnel. Fresh air, seized by the auxiliary fan, is taken by the flexible duct to the working face, from where is directed outwards by free flow and under influence of 
air pressure of the fan through the tube of the tunnel (Figure2). Cross-section area of each tunnel tube is

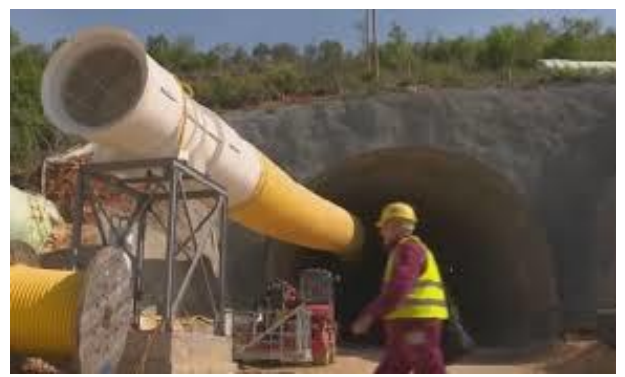

Figure 1 - Overview of the fan position and assembly
$68 \mathrm{~m}^{2}$. Figure 3 provides cross-section area of the tunnel with position of ducts for auxiliary ventilation.

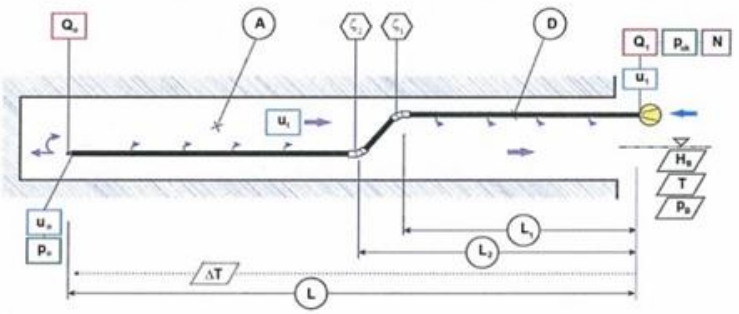

Figure 2 - Scheme of forcing auxiliary ventilation of single tube of the tunnel

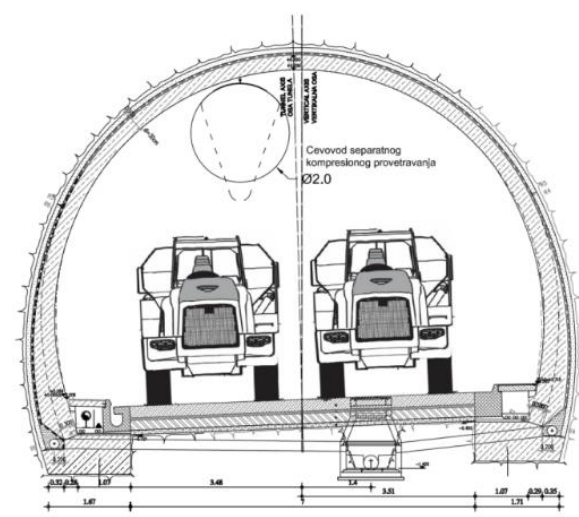

Figure 3 - Cross-section of the tube of the tunnel

\section{REQUIRED AMOUNT OF AIR FOR VENTILATION OF WORKS DURING TUNNEL CONSTRUCTION}

Excavation of complete profile of the tunnel is done in two phases: I phase calotte-crown and II phase bench and invert excavation

Excavation is mechanized, where drilling and blasting is used for harder rocks. Contour blasting is mandatory in case of drilling and blasting, in order to ensure required profile of tunnel. Support of the tunnel is according to specification of the New Austrian Tunnelling Method (NATM). According to NATM support system comprises of: shotcrete, steel mesh, rockbolts and steel arches. After complete excavation of full tunnel profile with securing-supporting, next step is excavation, securing and shotcreting of chambers, including shotcreting of invert excavation, bases, secondary lining, channels, roadsides and pedestrian paths.

Required amount of air for ventilation of tunnel during construction is calculated according to the Swiss standard SIA 196 (Schweizer Ingenieur- und Architekten-Verein: SIA Empfehlung 196: Baulüftung im Untertagebau) and German standard BGV C22 (Unfallverhütungsvorschrift Bauarbeiten BGV C 22. (ehem. VBG 37)). [5, 7] Criteria for calculation of required amount of air for ventilation are:
- Number of workers in the tunnel,

- Used diesel equipment for construction of the tunnel,

- Minimal allowed air speed in roadway, required for ventilation of gasses and suspended particles of dust.

Required amount of air after number of workers can be determined according to the German standard BGV C22 [7], which states that each worker requires 2 $\mathrm{m} 3 / \mathrm{min}$ of fresh air (Table 3).

Table 3. Required amount of fresh air after number of workers

\begin{tabular}{|l|l|l|l|}
\hline $\begin{array}{l}\text { Number of } \\
\text { workers in tunnel }\end{array}$ & $\begin{array}{l}\mathrm{QW}_{\mathrm{w}} \\
\left(\mathrm{m}^{3} / \mathrm{min} / \text { worker }\right)\end{array}$ & $\begin{array}{l}\mathrm{Qw}_{\text {tot }} \\
\left(\mathrm{m}^{3} / \mathrm{min}\right)\end{array}$ & $\begin{array}{l}\mathrm{Qw}_{\text {tot }} \\
\left(\mathrm{m}^{3} / \mathrm{s}\right)\end{array}$ \\
\hline 20 & 2 & 40 & 0.67 \\
\hline
\end{tabular}

Diesel powered equipment, specified in table 4 , will be used for all activities during construction of the tunnels and for achieving planned schedule. Requirements of Swiss standard SIA 196 [5] states that amount of fresh air for ventilation of tunnel with diesel powered equipment during construction, must not be less than $4 \mathrm{~m}^{3} / \mathrm{kW} / \mathrm{min}$ in case that equipment includes machines for excavation, loading and transport, or 2 $\mathrm{m}^{3} / \mathrm{kW} / \mathrm{min}$ in case that equipment is limited to shotcreting machines. In both cases machines are equipped with diesel particle filters - DPFs). 
This norm is in compliance with German standard BGV C22 [7]. Table 4 also provides required amount of air for dilution of exhaust from diesel engines in

Table 4. Specification of equipment planned for construction of tunnels and amounts of air

\begin{tabular}{|l|l|l|l|l|l|l|l|l|}
\hline Equipment type & $\begin{array}{l}\text { Power } \\
(\mathrm{kW})\end{array}$ & No. & $\begin{array}{l}\text { Total } \\
\text { power } \\
(\mathrm{kW})\end{array}$ & $\begin{array}{l}\text { Qair } / \mathrm{kW} \\
\left(\mathrm{m}^{3} / \mathrm{min}\right)\end{array}$ & $\begin{array}{l}\text { Load } \\
\text { Factor }\end{array}$ & $\begin{array}{l}\text { Time } \\
\text { factor } \\
(\%)\end{array}$ & $\begin{array}{l}\text { Qoptot } \\
\left(\mathrm{m}^{3} / \mathrm{min}\right)\end{array}$ & $\begin{array}{l}\text { Qoptot } \\
\left(\mathrm{m}^{3} / \mathrm{s}\right)\end{array}$ \\
\hline
\end{tabular}

Transport of material from the tunnel

\begin{tabular}{|l|l|l|l|l|l|l|l|l|}
\hline Loader Liebherr L-566 & 190 & 1 & 190 & 4 & 0.7 & 100 & 532 & 8.9 \\
\hline Articul. truck TEREX TA 30 & 261 & 2 & 522 & 4 & 0.7 & 100 & 1461.6 & 24.4 \\
\hline $\begin{array}{l}\text { Excavator with rotating } \\
\text { head Liebherr R 924 TC }\end{array}$ & 130 & 1 & 130 & 4 & 0.7 & 60 & 218.4 & 3.6 \\
\hline $\begin{array}{l}\text { Wheeled excavator } \\
\text { Hyundai R170 W-7A }\end{array}$ & 87 & 1 & 87 & 4 & 0.7 & 20 & 48.7 & 0.8 \\
\hline Roller Dynapac & 129 & 1 & 129 & 4 & 0.7 & 20 & 72.2 & 1.2 \\
\hline Total & & & & 2332.9 & 38.9 \\
\hline
\end{tabular}

Supporting, excavation and shotcreting

\begin{tabular}{|l|l|l|l|l|l|l|l|l|}
\hline $\begin{array}{l}\text { Excavator with rotating } \\
\text { head Liebherr R 924 TC }\end{array}$ & 130 & 1 & 130 & 4 & 0.7 & 100 & 364 & 6.1 \\
\hline $\begin{array}{l}\text { Shotcreting machine } \\
\text { Putzmeister Sistem Sika } \\
\text { PM 500 PC }\end{array}$ & 70 & 1 & 70 & 2 & - & 100 & 98 & 1.6 \\
\hline $\begin{array}{l}\text { Combined machine TEREX } \\
\text { 970 }\end{array}$ & 74.5 & 1 & 74.5 & 4 & 0.7 & 40 & 83.4 & 1.4 \\
\hline $\begin{array}{l}\text { Wheeled excavator } \\
\text { Hyundai R170 W-7A }\end{array}$ & 87 & 1 & 87 & 4 & 0.7 & 60 & 146.2 & 2.4 \\
\hline $\begin{array}{l}\text { Elevating platform ROTO } \\
\text { MERLO 40,25 }\end{array}$ & 107 & 1 & 107 & 4 & 0.7 & 80 & 239.7 & 3.9 \\
\hline $\begin{array}{l}\text { Mixers Schwing Stetter - } \\
\text { Mercedes-Benz 144 Actros }\end{array}$ & 320 & 2 & 640 & 2 & 0.7 & 100 & 1792 & 29.9 \\
\hline
\end{tabular}

It is obvious that dominant criterion is one for diesel powered equipment in case of using machines for supporting, excavation and shotcreting. Total required amount of air for ventilation during construction of tunnel is obtained by adding of required air for workers and air required for dilution of exhausts from diesel engines:

$$
Q_{t o t}=Q o p_{t o t}+Q w_{t o t}=46.0 \mathrm{~m}^{3} / \mathrm{s}
$$

According to the Swiss standard SIA 196 [5], average air speed in the tunnel must not be lower than $0.3 \mathrm{~m} / \mathrm{s}$. However, German standard BGV C22 [7] stipulates minimal speed of air in tunnel at $0.2 \mathrm{~m} / \mathrm{s}$, while British standard BS 6164 limits it at $0.5 \mathrm{~m} / \mathrm{s}$ [8].

It should be noted that investor required minimal air speed in the tunnel of at least $0.5 \mathrm{~m} / \mathrm{s}$. Therefore, verification of air flow speed, according to the total amount of air for ventilation of the tunnel, can be done as follows:

$$
u_{o}=Q_{t o t} / A_{t}=0.68 \mathrm{~m} / \mathrm{s}
$$

\section{CALCULATION OF AUXILIARY VENTILATION OF TUNNEL DURING CONSTRUCTION}

Auxiliary ventilation of tunnels "Suka", "Vežešnik", "Mrke" and "Vjeternik" during construction will be organized as shown on figure 2 . Ventilation of individual faces will include auxiliary axial fan and flexible duct $\varnothing 2.0 \mathrm{~m}$. Required amount of air for ventilation of faces is accepted at the amount of $\mathrm{Q}_{\mathrm{uk}}=46 \mathrm{~m}^{3} / \mathrm{s}$. It should be noted that construction of "Vežešnik" and "Vjeternik" tunnels will be organized from two sides, and this will imply certain maximal lengths of the ducts.

Calculation of forcing auxiliary ventilation is performed according to methodology described in detail in Swiss standard SIA 196 [5]. Calculation of auxiliary ventilation defines parameters of this system, 
which are later used for selection of auxiliary fan to be used for ventilation of working faces.

Overall pressure drop at the fan is defined as the sum of static pressure of the duct, dynamic pressure and sum of pressures of local losses along the duct, i.e.:

$$
p_{v}=p_{s t}+p_{d}+\sum_{1}^{i} p_{l o k i}
$$

where:

$$
\begin{aligned}
& p_{s t}-\text { static pressure of the duct, }[\mathrm{Pa}], \\
& p_{d} \quad-\text { dynamic pressure of the fan, }[\mathrm{Pa}], \\
& \sum_{1}^{i} p_{l o k i}-\text { sum of pressures of local losses along }
\end{aligned}
$$
the duct, $[\mathrm{Pa}]$.

Static pressure drop of the auxiliary ventilation duct is calculated as follows:

$$
\Delta p_{s t}=\lambda \frac{\Delta x}{D} \frac{\rho}{2} u_{x}^{2}
$$

where:

$\Delta p$ - static pressure drop along distance $\Delta \mathrm{x}$,

$\Delta x$ - length,

$\lambda$ - average friction coefficient of the duct,

$D$ - diameter of the duct,

$\rho$ - air density, duct.

$u_{x}$ - average air speed in considered part of the

Dynamic pressure drop is equal to:

$$
\Delta p_{d}=\frac{\rho}{2} u^{2}
$$

where $u$ is speed of air flow.

Pressure drops caused by local losses along the duct (changes of diameter, curves, and similar) are defined with following equation:

$$
\Delta p_{l o k}=\zeta \frac{\rho}{2} u^{2}
$$

where $\zeta$ is loss coefficient.

Total pressure drop at the fan can be written in integral form in following manner:

$$
p_{v}=p_{s t}+\frac{\rho}{2} u^{2}+\sum_{1}^{i} \zeta_{i} \frac{\rho}{2} u_{i}^{2}
$$

There are always losses caused by duct connections and minor damages caused by air outflow. In theory, it can be accepted that these losses are equally distributed along the length of the duct. Calculation method of standard SIA 196 [5] does not include large individual losses, which can be easily detected and, hence repaired (gluing of the thorn duct).

Losses of air outflow can then be calculated in relation to the area of outflow $\mathrm{f}^{*}$ and outflow velocity of air at locations of losses. Air velocity at outflow locations is proportional to the square root of static pressure of the loss.

Basic equation for static pressure change inside the duct, caused by the change of the flow due to loss of air is given by following equation:

$$
\begin{aligned}
& d p=\lambda \frac{\Delta x}{D} \frac{\rho}{2} u^{2} \\
& d u=\frac{4 f^{\prime}}{D} d x \sqrt{\frac{p}{\frac{\rho}{2}(1+\zeta)}}
\end{aligned}
$$

where:

$d u$ - change of average longitudinal speed along the length of the duct,

$f^{\prime}$ - area of the outflow loss at the duct connections,

$p$ - static pressure inside the duct.

This system of differential equations is solved by transformation into dimensionless form by introducing effective outflow area $\mathrm{f}^{*}$.

This transformation results in following system of differential equations:

$$
\begin{aligned}
& d \Pi=\lambda \frac{L}{D} \omega^{2} d \xi \\
& d \omega=4 f^{*} \frac{L}{D} \sqrt{\Pi} d \xi
\end{aligned}
$$

where:

$\Pi$ - dimensionless pressure inside the duct,

$\omega$-dimensionless ratio of speed and amount of air,

$\xi$-dimensionless length of the duct,

$f^{*}$ - effective outflow area.

Instead of solving this system of differential equations for determination of dimensionless ratio of speed or amount of air and pressure inside the duct, it is common practice to use diagrams (nomograms), which are also provided in standard SIA 196. [5]

Standard SIA 196 [2] uses three different classes of ducts, in relation to their quality:

B class: Duct already in operation or it is being used with regular maintenance (average outflow and friction losses)

A class: New, properly mounted with low duct damage risk (low outflow and friction losses), suitable only for "simple cases" 
S class: New, properly mounted and regularly maintained duct, with segments longer than $100 \mathrm{~m}$ and few connections (very low outflow and friction losses), suitable only for "simple cases" and duct storages.

Table 5 provides values of friction coefficients and effective areas of outflow for various classes of ducts.

In case of auxiliary ventilation calculation for construction of "Suka", "Vežešnik", "Mrke" and "Vjeternik" tunnels, class A duct will be planned. Diagram for this class of ducts is shown on figure 4 .
Table 5. Friction coefficient and effective outflow area for different classes of ducts [2]

\begin{tabular}{|l|l|l|}
\hline $\begin{array}{c}\text { Duct } \\
\text { class }\end{array}$ & $\begin{array}{c}\text { Friction } \\
\text { coefficient } \lambda\end{array}$ & \multicolumn{1}{|c|}{ Effective outflow area f* } \\
\hline $\mathrm{S}$ & 0.015 & $5 \times 10^{-6} \mathrm{~m}^{2} / \mathrm{m}^{2}=5 \mathrm{~mm}^{2} / \mathrm{m}^{2}$ \\
\hline $\mathrm{A}$ & 0.018 & $10 \times 10^{-6} \mathrm{~m}^{2} / \mathrm{m}^{2}=10 \mathrm{~mm}^{2} / \mathrm{m}^{2}$ \\
\hline $\mathrm{B}$ & 0.024 & $20 \times 10^{-6} \mathrm{~m}^{2} / \mathrm{m}^{2}=20 \mathrm{~mm}^{2} / \mathrm{m}^{2}$ \\
\hline
\end{tabular}

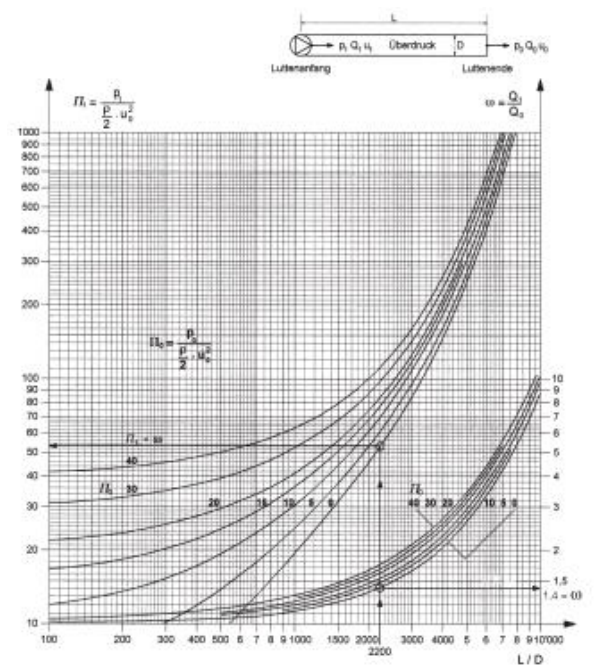

Figure 4 - Diagram for determination of dimensionless ratio of air amount and dimensionless pressure inside the duct, for class A duct ( $\lambda=0.0018$ and $\left.f^{*}=10 \mathrm{~mm}^{2} / \mathrm{m}^{2}\right)$ [2]Results of the auxiliary ventilation parameters calculation for construction of "Suka", "Vežešnik", "Mrke" and "Vjeternik" tunnels, according to SIA 196 standard [5], are given in table 6, which will be used for fan selection

\section{FAN SELECTION}

Project includes application of frequency regulation for electric drive motors of the fan. Some manufacturers of fans are providing regulation of operational parameters by frequency regulation in $1 \mathrm{~Hz}$ increments.

This capability will ensure planned air flow along the tunnel and at the working face, without consequences to working conditions during construction of the tunnel. Further on we will provide an example of axial fan selection for auxiliary ventilation of construction of "Suka", "Vežešnik", "Mrke" and "Vjeternik" tunnel, manufactured by Korfmann Company. It should be noted that other fans with similar characteristics can be used.

Diagrams are including duct properties of analysed tunnels. Properties of the AL 16-1320 and AL 16-900 fans, manufactured by Korfmann, are shown on diagram presented at figure 5, including properties of the duct. This figure includes all four tunnels.

Table 6. Results of auxiliary ventilation calculation during construction phase of the tunnels

\begin{tabular}{|c|c|c|c|c|}
\hline \multirow{2}{*}{ Input data } & \multicolumn{4}{|l|}{ Tunnel } \\
\hline & Mrke & Suka & Vežešnik & Vjeternik \\
\hline Duct length $(\mathrm{m})$ : & 860 & 740 & 1280 & 1540 \\
\hline Tunnel cross section area $\left(\mathrm{m}^{2}\right)$ : & 68 & 68 & 68 & 68 \\
\hline Required amount of air $\mathrm{Q}_{0}\left(\mathrm{~m}^{3} / \mathrm{s}\right)$ : & 46 & 46 & 46 & 46 \\
\hline Duct diameter $(\mathrm{m})$ & 2 & 2 & 2 & 2 \\
\hline \multicolumn{5}{|l|}{ Calculation results } \\
\hline Amount of air at the fan $\mathrm{Q}_{1}\left(\mathrm{~m}^{3} / \mathrm{s}\right)$ & 47.8 & 47.4 & 49.2 & 49.7 \\
\hline Total duct pressure at the fan $(\mathrm{Pa})$ & 1454.54 & 1269.93 & 1968.23 & 2193.79 \\
\hline Required power at the fan $(\mathrm{kW})$ & 95.5 & 80 & 128.8 & 144.9 \\
\hline
\end{tabular}




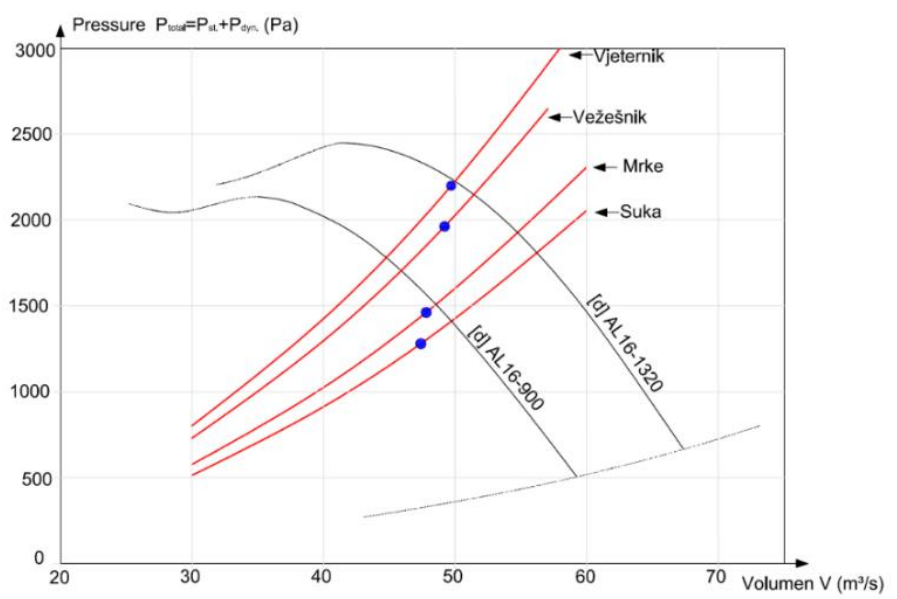

Figure 5 - Diagram of the AL 16-1320 and AL 16-900 fans by Korfmann, with duct properties, for ventilation of "Suka", "Vežešnik", "Mrke" and "Vjeternik" tunnels

Construction of the tunnels includes construction of the rescue passages for people and vehicles, at distance of every $250 \mathrm{~m}$. To provide stable ventilation system for each tunnel tube, it is common that these transversal connections are closed immediately after finishing their construction. This should prevent their impact on planned auxiliary ventilation in remaining part of the tunnel. Isolation can be achieved, depending on the situation, by ventilation curtains of flexible brattices, in case these passages should be used. It should be noted that in case of such parallel and identical tunnel tubes, with same auxiliary ventilation, even opened passages will not have significant impact on the ventilation. In any case, it is necessary to perform measurement of air flow and to control the distribution. This approach would eliminate any possible impact of machinery operation in the other tube of the tunnel.

\section{CONCLUSION}

Road Belgrade-Adriatic Sea (Bar) is extension of Trans-European Highway (TEH) with the purpose to connects main TEH route (Gdansk, Poland and Athens, Greece and Istanbul, Turkey) with the Adriatic Sea in the Montenegro. Bar-Boljare highway is a part of the TEH through Montenegro. According to the situation on terrain, construction of several tunnels was an only possible solution for the highway development. This paper presents case study on ventilation method development for the highway tunnels construction and it includes ventilation solutions for tunnels "Suka", "Vežešnik", "Mrke" and Vjeternik" during construction phase. Widely accepted major construction ventilation schemes are proposing to organize ventilation as forcing auxiliary ventilation of underground openings, with flexible ducts to introduce fresh air directly to the work sites. Due to lack of local regulations on air requirements during tunnel construction, required amount of air is calculated in accordance to the
Swiss standard SIA 196 (Schweizer Ingenieur- und Architekten-Verein: SIA Empfehlung 196: Baulüftung im Untertagebau) and German standard BGV C22 (Unfallverhütungsvorschrift Bauarbeiten BGV C22. (ehem. VBG 37)).

\section{ACKNOWLEDGEMENT}

Research described in this paper was performed during development of the project "Research on possibility for AT (Advanced Technology) rockbolting application in mines for the purpose of increasing work safety and production efficiency" (TR 33025). Development of this project is financed by Ministry of Education, Science and Technological Development, Republic of Serbia.

\section{REFERENCES}

[1] Kolymbas D, Tunnelling and Tunnel Mechanics - $a$ Rational Approach to Tunnelling, e-ISBN 978-3540-28500-7, Springer-Verlag Berlin Heidelberg, 2008.

[2] Drost U, Bettelini M., INELMEC SA, Switzerland, Tunnel Construction Site Ventilation and Cooling: An Integrated Flow and Heat Load Solver Applied to the Lyon-Turin High-Speed Railroad Tunnel Project, TMI International Conference: Tunnel protection and security against fire and other hazards, Torino, Italy, 15-16. May 2006.

[3] Caissenationale de l'assurance maladie des travailleurs salaries, „Mise en ouvre de dispositifs de ventilation mécanique lors des travaux de creusement en souterrains de galeries, de puits, ou degrandes excavations“, Recommandation R352 adoptée le 27 juin1990.

[4] AFTES (France), „Recommandations Relatives à la Ventilation des Ouvrages Souterrains en Cours de Construction“", p. 76-106, Tunnels et ouvrages souterrains $-\mathrm{N}^{\circ} 176$, mars/avril 2003. 
[5] SIA 196 - Recommendation - Edition 1998, Ventilation in underground construction, Swiss Engineering and Architects Association.

[6] Ventilation project of tunnels "Mrke", "Suka", "Vežešnik" and "Vjeternik" during construction, VOLMONT MD d.o.o, Podgorica, 2015.
[7] German standard BGV C22 (Unfallverhütungsvorschrift Bauarbeiten BGV C22. (ehem. VBG 37)).

[8] British Standard BS 6164:2011 Code of practice for health and safety in tunnelling in the construction industry.

\section{REZIME}

\section{REŠENJE VENTILACIJE TUNELA NA AUTOPUTU BAR-BOLJARE U CRNOJ GORI U FAZI NJIHOVE IZRADE}

Ponekad je gradnja tunela neophodna, bez obzira na njegovu namenu, iz više razloga, a neki od njih su: ograničen prostor, siguran rad, zaštita okoline itd. U takvim slučajevima jedan od glavnih aspekata, sa stanovišta projektovanja tunela, je i ventilacija tokom njihove izrade. Ventilacija je potrebna za vreme izgradnje bilo kojeg tunela, bez obzira na tehnologiju kojom se gradi. Uobičajeno se primenjuju tri glavne sheme ventilacije. Koja će biti korišćena često zavisi od uslova konkretne lokacije. U radu je prikazano rešenje ventilacije tunela „,Suka“, „,Vežešnik“, „Mrke“ i „Vjeternik“ tokom njihove izrade. Tuneli su deo autoputa Bar-Boljare koji predstavlja deonicu Trans-Evropskog magistrale (THE) na njenom delu kroz Republiku Crnu Goru.

Ključne reči: izrada tunela, ventilacija, Bar-Boljare autoput 